\title{
Our Retrograde Intrarenal Surgery Experience with Horseshoe Kidney
}

\author{
At Nalı Böbrekte Retrograd Intrarenal Cerrahi Deneyimlerimiz
}

\author{
Tufan Süelözgen, Cemal Selçuk İşoğlu, Mustafa Karabıçak, Mehmet Yiğit Yalçın, Sezgin Yeni, Yusuf Özlem İlbey \\ University of Health Sciences, Tepecik Training and Research Hospital, Clinic of Urology, Izmir, Turkiye
}

\begin{abstract}
What's known on the subject? and What does the study add?
Retrograde intrarenal surgery is currently popular, and at present it is seen as an alternative approach to percutaneous nephrolithotomy for stones over $2 \mathrm{~cm}$. A threshold number for the learning curve is not available in the literature. Therefore, it should be performed in experienced centers in kidneys that do not have a normal anatomy like a horseshoe kidney.
\end{abstract}

\section{Abstract}

Objective: To share our experience with retrograde intrarenal surgery (RIRS) done in patients with horseshoe kidney anomaly.

Materials and Methods: Data from 107 patients who underwent RIRS for kidney stones between 2013 and 2016 in our clinic was retrospectively analyzed and 6 patients with horseshoe kidney anomaly detected on computed tomography (CT) were included in the study. Achieving stone-free status or having residual stones of $\leq 4 \mathrm{~mm}$ were considered operational success.

Results: The mean age of the patients was $44.5 \pm 6.7$ years. Four patients were male $(66.6 \%)$ and two were female $(33.3 \%)$. The mean stone size was $14.5 \pm 4.1(10-22) \mathrm{mm}$. Three patients had pelvis stones (50\%) and the rest $3(50 \%)$ had lower calyx stones. Two patients (33.3\%) were found to be stone-free on post-operative non-contrast CT results.

Conclusion: RIRS should be performed by experienced surgeons in patients with horseshoe kidney.

Keywords: Kidney stone, horseshoe kidney, retrograde intrarenal surgery

Öz

Amaç: Amacımız at nalı böbrek anomalisine sahip hastalardaki retrograd intrarenal cerrahi (RIRC) deneyimlerimizi paylaşmaktır.

Gereç ve Yöntem: 2013-2016 yılları arasında kliniğimizde RIRC yapılan 107 hastanın verileri geriye dönük olarak incelendi ve bilgisayarlı tomografide (BT) at nalı böbrek anomalisine sahip olduğu belirlenen 6 hasta çalışmaya dahil edildi. Tamamen taşsızlık veya 4 mm'den daha az rezidü operasyon başarısı olarak kabul edildi.

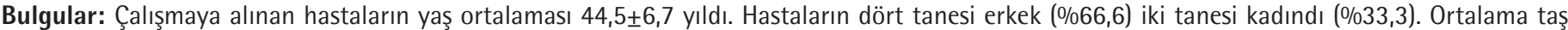
boyutu 14,5 $\pm 4,1$ (10-22) mm idi. Üç hastada pelvis taşı (\%50) ve kalan üç hastada ise alt kaliks taşı mevcuttu. Postoperatif istenen kontrastsız BT'de iki hastada $(\% 33,3)$ taşsızlık izlendi.

Sonuç: At nalı böbrek anomalisine sahip hastalarda RIRC deneyimli cerrahlar tarafından uygulanmalıdır.

Anahtar Kelimeler: Böbrek taşı, at nalı böbrek, retrograd intrarenal cerrahi

\section{Introduction}

The main goal in kidney stone treatment is to achieve the longest stone-free period with the smallest morbidity rate as possible. The search for less invasive techniques and the technological developments are still ongoing. Today, the primary approach for renal stones larger than $2 \mathrm{~cm}$ in diameter is percutaneous nephrolithotomy (PNL). However, another possible first-choice option is retrograde intrarenal surgery (RIRS), especially in extracorporeal shock wave lithotripsy (ESWL)-resistant stones

Correspondence: Tufan Süelözgen MD, University of Health Sciences, Tepecik Training and Research Hospital, Clinic of Urology, İzmir, Turkiye Phone: +90 2323696969 E-mail: tsuelozgen@hotmail.com ORCID ID: orcid.org/0000-0003-0790-3926 Received: 29.01.2017 Accepted: 08.04.2017

Cite this article as: Süelözgen T, İşoğlu CS, Karabıçak M, Yalçın MY, Yeni S, İlbey YÖ. Our Retrograde Intrarenal Surgery Experience with Horseshoe Kidney. J Urol Surg 2017;4:106-108.

๑Copyright 2017 by the Association of Urological Surgery / Journal of Urological Surgery published by Galenos Publishing House. 
measuring 1-2 cm in diameter (1). Although RIRS is a relatively common treatment method for kidney stones recently, there are not many publications about RIRS in horseshoe kidneys. Therefore, we would like to share our experience with RIRS surgery done in patients with horseshoe kidney anomaly.

\section{Materials and Methods}

Data from 107 patients who underwent RIRS for kidney stones between 2013 and 2016 in our clinic was retrospectively reviewed. Patients over 18 years of age with full set of demographic and post-operative data were included in the study. Patients with horseshoe kidney anomaly detected on computed tomography (CT) were included in the study. Patients' data were reviewed in terms of age, sex, stone location, stone diameter, stone-free status and post-operative complications. The longest axis of the stone measured was recorded as the stone diameter. Success status was defined as either no residue or a residue smaller than $4 \mathrm{~mm}$ on control CT taken on the $1^{\text {st }}$ month of operation. Due to the retrospective nature of our study, there was no available data on patients who had residual stones after surgery.

\section{Procedure}

The procedure was performed under general anesthesia after urine cultures were detected as sterile. Patient was positioned from trendelenburg position to lithotomy position. Orifices were checked using a $22 \mathrm{~F}$ cystoscope. Routine rigid ureterorenoscopy and routine stenting were not performed before operation. Following insertion of a hydrophilic guide catheter, a 9.5-12F urethral access sheet was introduced. A flexible ureterorenoscopy was placed (Storz Flex $\mathrm{X}^{\circ}$ ) and stones were fragmented using the Holmium-YAG laser (Litho 20 W Quantasystem ${ }^{\circ}$ ). Laser energy was adjusted to 0.8 1 Joule and the frequency was set as 5-8 Hz. A $200 \mu \mathrm{m}$ laser probe was used. Dusting method is preferred for lithotripsy. All patients received a routine post-operative double-J stent (DJS) following surgery.

\section{Results}

A total of six patients with horseshoe kidney anomaly were included in the study. The mean age of the patients was $44.5 \pm 6.7$ years. Four patients were male $(66.6 \%)$ and two were female (33.3\%). The mean stone size was $14.5 \pm 4.1$ (10-22) $\mathrm{mm}$ and all stones were opaque. Three patients had pelvis stone $(50 \%)$ and the rest $3(50 \%)$ had lower calyx stones. Except for one patient, none of the patients required a preoperative DJS. Three (50\%) patients had a previous ESWL history. Two patients (33.3\%) were stone-free according to the post-operative noncontrast CT results (Table 1). None of the patients showed any intraoperative or early post-operative complication.

\section{Discussion}

Fuchs and Fuchs (2) have reported the first RIRS experience using a flexible ureterorenoscopy in 1990. With the recent advances in technology in addition to widespread use of the technique, today RIRS is used along with ESWL and PNL for kidney stone management. RIRS gained more popularity with similar stonefree rates and low complication profile seen in PNL technique (3). Lately, some authors argue that RIRS is a viable treatment option in treating $1-4 \mathrm{~cm}$ stones $(4,5)$.

The European Association of Urology guidelines use stone size and location for determining treatment algorithm in kidney stones (1). However, kidney stone management in kidney anomalies is still a controversial subject. A study reported RIRS as a first-line treatment option in difficult cases such as bleeding diathesis, urinary diversion, morbid obesity, horseshoe kidney or calyx diverticulitis (6). In our study, we discussed the results of RIRS in our patients with horseshoe kidney anomaly.

Horseshoe kidney is the most commonly diagnosed fusion anomaly in kidneys. It is seen in 1 out of 400 live births. This anomaly is characterized by the anterior position of the renal pelvis and higher placement of ureteral exit. It causes insufficient drainage, urinary stasis and tendency for stone formation (7).

Table 1. Pre- and post-operative data of the patients included

\begin{tabular}{|c|c|c|c|c|c|c|c|c|c|}
\hline & Age & Sex & $\begin{array}{l}\text { Pre-operative } \\
\text { ESWL }\end{array}$ & $\begin{array}{l}\text { Stone } \\
\text { localization }\end{array}$ & $\begin{array}{l}\text { Preoperative } \\
\text { DJS }\end{array}$ & $\begin{array}{l}\text { Stone } \\
\text { size }(\mathrm{mm})\end{array}$ & Stone-free & $\begin{array}{l}\text { Intraoperative } \\
\text { complications }\end{array}$ & $\begin{array}{l}\text { Post-operative } \\
\text { complications }\end{array}$ \\
\hline Patient 1 & 58 & Female & No & Pelvis & Yes & 22 & No & No & No \\
\hline Patient 2 & 50 & Male & Yes & Lower calyx & No & 10 & No & No & No \\
\hline Patient 3 & 58 & Female & No & Lower calyx & No & 13 & No & No & No \\
\hline Patient 4 & 49 & Male & Yes & Pelvis & No & 15 & No & No & No \\
\hline Patient 5 & 33 & Male & No & Lower calyx & No & 12 & Yes & No & No \\
\hline Patient 6 & 19 & Male & No & Pelvis & No & 15 & Yes & No & No \\
\hline
\end{tabular}

ESWL: Extracorporeal shock wave lithotripsy, DJS: Double-J stent 
RIRS in horseshoe kidney was first reported in 2005 in a study including four patients with horseshoe kidneys and stone-free status was achieved in 3 of them (8). Another study including 17 patients done by Molimard et al. (9) reported a stone-free rate of $88.2 \%$. No major complications were reported and the success rate was found to be comparable to PNL results. The study reported a mean stone size as $16 \mathrm{~mm}$ and all surgeries were performed by very experienced surgeons (9). Another study reported a stone-free rate of 70\% in 25 renal units and low complication rates (10). Gokce et al. (11) in their study done on 23 patients, reported a stone-free rate of $73.9 \%$ with a mean stone size of $16.9 \pm 4.1 \mathrm{~mm}$.

In our study, stone-free status was achieved in two (33\%) patients based on non-contrast CT 1 month after surgery. This is a relatively low success rate in comparison with the results of the previous studies in the literature. This is thought to be caused by the insufficient experience with RIRS surgery in our clinic. In addition, the surgeries were not all performed by the same surgeon.

\section{Study Limitations}

There are not enough learning curve studies, thus, the sufficiency of RIRS technique (12). For that reason, we could not find a clear answer to the question "when RIRS should be performed in kidney anomalies?" However, one should be certain that the surgeon is experienced enough before attempting to use this technique in surgery of kidneys with anomalies. The main limitations of the study include its retrospective design, relatively low number of patients and the fact that the surgeries were not performed by the same surgeon.

\section{Conclusion}

For high stone-free rates, RIRS for horseshoe kidneys should be performed in experienced centers.

\section{Ethics}

Ethics Committee Approval: Retrospective study.

Informed Consent: Retrospective study.

Peer-review: Externally peer-reviewed.

\section{Authorship Contributions}

Surgical and Medical Practices: T.S., C.S.I., Concept: Y.Ö.I., Design: T.S., C.S.I., Data Collection or Processing: M.K., M.Y.Y.,
S.Y., Analysis or Interpretation: Y.Ö.I., Literature Search: T.S., C.S.I., Writing: T.S., C.S.I.

Conflict of Interest: No conflict of interest was declared by the authors.

Financial Disclosure: The authors declared that this study received no financial support.

\section{References}

1. Türk C, Knoll T, Petrik A, Sarica K, Skolarikos A, Straub M, Seitz C. Guidelines on Urolithiasis. European Association of Urology, 2016.

2. Fuchs $G j$, Fuchs AM. Flexible endoscopy of the upper urinary tract. A new minimally invasive method for diagnosis and treatment. Urologe $A$ 1990;29:313-320.

3. Bozkurt OF, Resorlu B, Yildiz Y, Can CE, Unsal A. Retrograde intrarenal surgery versus percutaneous nephrolithotomy in the management of lowerpolerenal stones with a diameter of 15 to $20 \mathrm{~mm}$. J Endourol 2011;25:11311135.

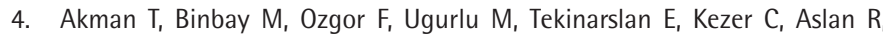
Muslumanoglu AY. Comparison of percutaneous nephrolithotomy and retrograde flexible nephrolithotripsy for the management of 2-4 cm stones: a matched-pair analysis. BJU Int 2012;109:1384-1389.

5. Akman $T$, Binbay $M$, Ugurlu $M$, Kaba $M$, Akcay $M$, Yazici O, Ozgor $F$, Muslumanoglu AY. Outcomes of retrograde intrarenal surgery compared with percutaneous nephrolithotomy in elderly patients with moderate-size kidney stones: a matched-pair analysis. J Endourology 2012;26:625-629.

6. Papatsoris A, Sarica K. Flexible ureterorenoscopic management of upper tract pathologies. Urol Res 2012;40:639-646.

7. Bauer $S$. Anomalies of the upper urinary tract. In: Walsh $P C_{1}$ Retic $A B$, Vaughan E. Campbell's Urology, 8th ed. Philadelphia, Elsevier Saunders, 2002.

8. Weizer AZ, Springhart WP, Ekeruo WO, Matlaga BR, Tan YH, Assimos DG, Preminger GM. Ureteroscopic management of renal calculi in anomalous kidneys. Urology 2005;65:265-269.

9. Molimard B, Al-Qahtani S, Lakmichi A, Sejiny M, Gil-Diez de Medina S, Carpentier $\mathrm{X}$, Traxer 0 . Flexible ureterorenoscopy with holmium laser in horseshoe kidneys. Urology 2010;76:1334-1337.

10. Atis G, Resorlu B, Gurbuz C, Arikan O, Ozyuvali E, Unsal A, Caskurlu T. Retrograde intrarenal surgery in patients with horseshoe kidneys. Urolithiasis 2013;41:79-83.

11. Gokce MI, Tokatli Z, Suer E, Hajiyev P, Akinci A, Esen B. Comparison of shock wave lithotripsy (SWL) and retrograde intrarenal surgery (RIRS) for treatment of stone disease in horseshoe kidney patients. Int Braz J Urol 2016; 42:96-100.

12. Cho SY, Choo MS, Jung JH, Jeong CW, Oh S, Lee SB, Son $H$, Jeong $H$. Cumulative Sum Analysis for Experiences of a Single-Session Retrograde Intrarenal Stone Surgery and Analysis of Predictors for Stone-Free Status. PLOS ONE 2014;9:e84878. 